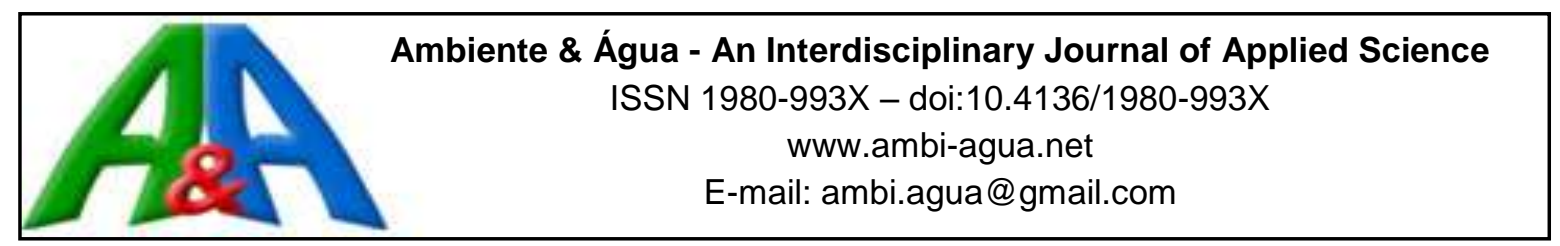

\title{
Distribution and contamination of metals in the soil of Guandu Watershed
}

\author{
doi:10.4136/ambi-agua.1639
}

Received: 03 May 2015; Accepted: 25 Aug. 2015

\author{
Aldo Pacheco Ferreira \\ Escola Nacional de Saúde Pública Sergio Arouca (Ensp), Manguinhos, RJ, Brasil \\ e-mail: aldopachecoferreira@gmail.com
}

\begin{abstract}
Coastal areas provide important benefits to humans in terms of food resources and ecosystem services. At the same time, human activities can have significant negative impacts on ecosystem health. Thus, control of watershed pollution is both necessary and essential in order to reduce and systematically eliminate the detrimental consequences that are evident in marine and estuarine ecosystems. The present study investigated the distribution of metals at the Guandu Watershed. Five sampling sites were selected for the soil analysis. Samples were collected from February 2013 to December 2014 and analysed for concentrations of As, Cd, $\mathrm{Zn}, \mathrm{Cu}, \mathrm{Pb}, \mathrm{Cr}, \mathrm{Ni}$, and $\mathrm{Co}$, using ICP. For control, some samples were used in uncontaminated areas outside the direct effect of chemical industries. The data indicate the presence of metals at the research sites. While the levels of contamination are still slightly below the peak concentrations established by Brazilian legislation, they are approaching levels of concern, particularly with regard to $\mathrm{As}, \mathrm{Cd}, \mathrm{Pb}$ and $\mathrm{Cr}$. The results indicate that the use of water from the Guandu Watershed for recreational purposes and fishing is harmful to both human health and the environment.
\end{abstract}

Keywords: environmental assessment, pollution, trace elements.

\section{Distribuição e contaminação de metais no solo da bacia hidrográfica do Rio Guandu}

\section{RESUMO}

As zonas costeiras proporcionam benefícios importantes para os seres humanos em termos de recursos alimentares e serviços ecossistêmicos. Ao mesmo tempo, as atividades humanas podem ter impactos negativos significativos sobre a saúde dos ecossistemas. Assim, o controle da poluição das bacias hidrográficas, além de necessária, é fundamental para reduzir e sistematicamente eliminar as atuais consequências impactantes que são evidentes nos ecossistemas marinhos e estuarinos. O presente estudo investigou a distribuição de metais na bacia hidrográfica do Rio Guandu. Cinco pontos de amostragem foram selecionados para as análises de solo. As amostras foram coletadas a partir de fevereiro a novembro de 2014, e analisadas para as concentrações de $\mathrm{As}, \mathrm{Cd}, \mathrm{Zn}, \mathrm{Cu}, \mathrm{Pb}, \mathrm{Cr}$, Ni e $\mathrm{Co}$, utilizando ICP. Para o controle, algumas amostras foram utilizadas em áreas não-contaminadas, fora do efeito direto das indústrias químicas. Os dados indicam a presença dos metais pesquisados no solo dos 
locais de pesquisa estão contaminados; ainda que levemente abaixo das concentrações máximas estabelecidas por referência brasileira, mas atingindo concentrações preocupantes, destacando $\mathrm{As}, \mathrm{Cd}, \mathrm{Pb}$ e $\mathrm{Cr}$. No que diz respeito aos resultados, sinaliza que o uso da água da bacia hidrográfica do Guandu para fins recreativos e pesca é prejudicial para a saúde humana e ambiente.

Palavras-chave: avaliação ambiental, análise de solo, elementos-traço, poluição.

\section{INTRODUCTION}

The entry of contaminants into the environment due to human and natural activities is one of the most important issues facing today's communities. Due to industrial and economic growth and the production of a variety of compounds and chemicals well as increased consumption, man creates various unwanted pollutants, many of which cause serious problems and risks for the environment and for man himself (Shanbehzadeh et al., 2014).

Metals are among the most common environmental contaminants, and persist for long periods in the environment, mainly in soil. They therefore represent a potential threat to biodiversity and ecosystems. In addition, in aquatic ecosystems, these elements can undergo chemical transformations that make them even more harmful to the environment. High concentrations of $\mathrm{Cd}, \mathrm{Hg}, \mathrm{Pb}, \mathrm{Zn}, \mathrm{Cu}, \mathrm{Ni}$ and semimetals such as As, for example, may have harmful effects on aquatic organisms or predators, since these are biomagnified in the food chain (Ferreira and Horta, 2010; Miranda Filho et al., 2011).

The ingress of municipal, industrial, and agricultural waste is another source of human environmental pollution. Water, including surface water such as rivers, is among the most critical of resources, and its importance in meeting the needs of humans, animals and industries indicates the essential need to protect it from contamination. As municipal, industrial, and agricultural wastes enter water, biological and chemical contaminants including metals enter as well. Although some of these metals are essential as micronutrients, their high concentration in the food chain can cause toxicity and environmental impacts and endanger aquatic ecosystems and their users (Sherman et al., 2015).

Contaminated sediments do not always remain at the bottom of a water body. Anything that stirs up the water, such as dredging, can re-suspend sediments (Binning and Baird, 2001). Re-suspension may mean that all of the animals in the water, and not just the bottom dwelling organisms, will be directly exposed to toxic contaminants (Temmerman et al., 2013). Different aquatic organisms often respond to external contamination in different ways, and the quantity and form of the element in the water, sediment, or food will determine the degree of accumulation (Casado-Martínez et al., 2006). Many dangerous chemical elements, if released into the environment, accumulate in soil and water bodies. Under certain conditions, chemical elements accumulated in the silt and bottom sediments of water bodies can migrate back into the water. Silt can become a secondary source of metal pollution (Frignani and Bellucci, 2004; Li et al., 2013a). Sediments are likewise a significant repository for metal pollutants that enter the sea. Sediments provide habitats for many aquatic organisms and are also a major repository for many of the more persistent chemicals that are introduced into surface waters. Most anthropogenic chemicals and waste materials, including toxic organic and inorganic chemicals, eventually accumulate in sediments. In aquatic environments, many metals are transported predominantly in association with particulate matter, and consequently, a high concentration of metals is often detected in sediments in many industrialized harbours and coastal regions around the world (US-EPA, 1999; Bertolotto et al., 2005; Wang et al., 2007; Ferreira, 2011). 
Industrial development and population growth in recent decades, and in particular growth in sectors linked to the production of energy, are related to a large number of human actions that endanger the environment (Slatin, 2011). Energy is often the foundational issue upon which the developmental plans of nations rest; however, governments, society, research institutions and companies themselves must be responsible for generating responsible and sustainable management of natural resources (Cahen, 2006).

Management of water resources is difficult. Two extremes must be considered in determining the effluent load that may be sustainably adsorbed by a water body. First, the cost of the effluent treatment facilities, which increases with the degree of treatment required; and second, the capacity of the receiving water body to absorb this surplus pollution. Domestic and industrial wastewater effluents into rivers, the use of fertilizers and pesticides, soil degradation caused by deforestation, landfills and mining are the major drivers impacting on the country's water resources (Leal Neto et al., 2006). The environmental impacts arising from various pollution sources make clear that there is urgency for concrete actions to prevent, control, preserve and restore water quality (Freitas et al., 2001). In this context, scientific research guides actions to mitigate impacts on water resources, thereby increasing their effectiveness (Ferreira, 2010).

Metals are favourably transferred from the dissolved to the particulate phase and this is reflected in their concentration in marine soil. Consequently, concentrations of metals frequently exceed those in overlying water by several orders of magnitude (Wang et al., 2013). When soil stores metals, concentrations can become elevated and potentially toxic. Exposure and uptake of even a small fraction of soil-bound metal by organisms could have a significant toxicological effect, particularly where circumstances favour bioavailability. In addition, increased metal concentrations in pore water may further enhance soil toxicity (Gray and Shadbegian, 2004).

This study applied a systems approach in order to develop a global assessment of the importance of changes in river catchments and impacts on coastal seas, using the Guandu watershed as a model, Figure 1 shows a framework of the study area, focusing on the horizontal flux of substances within the catchment coastal zone system. This systems approach, integrating natural and social sciences, addresses such issues as critical concentrations and loads, resilience and carrying capacity.

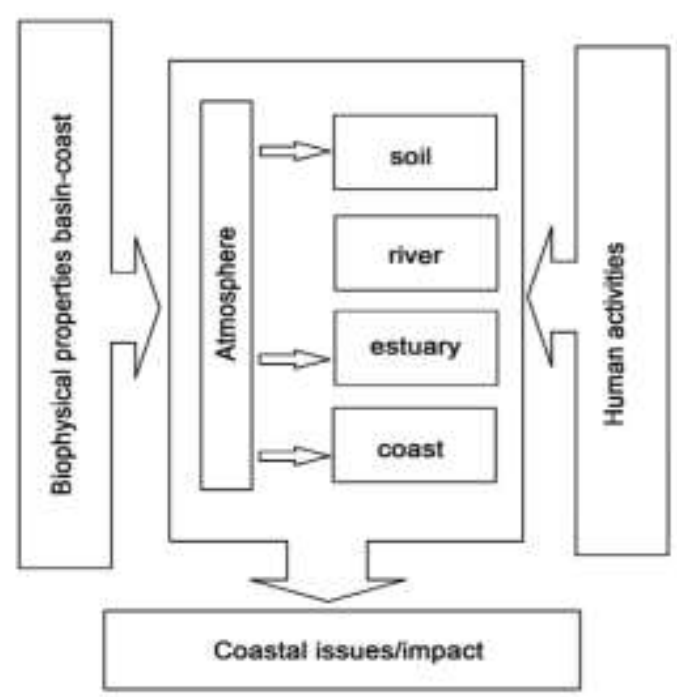

Figure 1. Framework of impact on coastal zone system: environmental pressures. Source: Meybeck et al. (2006). 
Apart from direct inputs into rivers, atmospheric deposition of pollutants on basins and transport by runoff also contributes significantly to increasing metal concentrations in coastal seas (Li et al., 2013b). This is particularly important for metals, whose cycles include a significant atmospheric component. Even relatively remote areas show abnormal concentrations. Accelerated land-use changes in coastal basins also contribute to the remobilization of deposited pollutants on soil (Landrot et al., 2012).

There is a lack of information in Brazil regarding pollutant emissions by industrial activities (Costa et al., 2011). Moreover, there is no national inventory of potentially polluting industries, with data on the amount of pollutants and their location. Monitoring systems at emission sources are poor and / or absent. These systems require specialized personnel and should be performed continuously during the procedure. In this context, where data are scarce and pollution emission monitoring is not performed, methodologies which estimate pollutant emissions are extremely important tools. These methodologies make it possible to define critical areas of pollution and rank the most polluting industrial typologies where the government can focus its efforts on pollution mitigation.

Brazilian soil guidance values are established by CONAMA (2009), which includes guiding quality values for the presence of chemical substances and establishing guidelines for environmental management of areas contaminated by these substances as a result of human activities. These values indicate the soil quality capable of supporting their primary function, protecting the ecological receptors. The intervention value is the concentration of a substance in the soil beyond which there are potential direct and indirect risks to human health, considering a generic exposure scenario. Toxic components and / or substances included in the list of Guiding Values for soil are presented in Table 1.

Table 1. Toxic elements and / or substances of Guiding Values for Soil (mg.kg-1 dry weight).

\begin{tabular}{cccc}
\hline \multirow{2}{*}{ Element } & $\begin{array}{c}\text { Quality reference } \\
\text { value }\end{array}$ & \multicolumn{2}{c}{ Intervention } \\
\cline { 3 - 4 } & 3.5 & Residential & Industrial \\
\hline $\mathrm{As}$ & $<0.5$ & 85 & 150 \\
$\mathrm{Cd}$ & 60 & 1000 & 20 \\
$\mathrm{Zn}$ & 35 & 400 & 600 \\
$\mathrm{Cu}$ & 17 & 300 & 900 \\
$\mathrm{~Pb}$ & 40 & 40 & 75 \\
$\mathrm{Cr}$ & 13 & 100 & 130 \\
$\mathrm{Ni}$ & 13 & 65 & 90 \\
$\mathrm{Co}$ & & &
\end{tabular}

Source: CONAMA (2009).

In economic terms, Sepetiba Bay is strategicly located. It has a radius of $500 \mathrm{~km}$ and generates about $70 \%$ of gross national product - GDP (Firjan, 2005). The federal government also predicts new industrial complexes installation in the region. The Growth Acceleration Program (GAP), among its objectives, seeks to expand the Sepetiba port and its connections to main federal highways, as well as investments in petrochemical programs, local housing and sanitation. Therefore, the goal of this study was to compare soil contaminated by metals to pristine soil (control areas) within the industrial zone of the Guandu Watershed, Rio de Janeiro, Brazil. 


\section{MATERIALS AND METHODS}

\subsection{Study site: Guandu watershed}

The Guandu watershed is located in the State of Rio de Janeiro, Brazil, (coordinates UTM 7420000/6400000 extreme NW and 7483500/6880000 extreme SE), with a $1921 \mathrm{~km}^{2}$ drainage area. It contributions to Sepetiba Bay have two main sources: the Serra do Mar mountain chain and an extensive area of lowland, crossed by many rivers, consisting of 22 sub-basins. The main rivers within the catchment area of Sepetiba Bay and its respective average flow are the Guandu River, also known as the Channel of San Francisco $\left(89 \mathrm{~m}^{3} \mathrm{~s}^{-1}\right)$; the Guarda River $\left(6.8 \mathrm{~m}^{3} \mathrm{~s}^{-1}\right)$; Ita channel $\left(3.3 \mathrm{~m}^{3} \mathrm{~s}^{-1}\right)$; the Piraquê River $\left(2.5 \mathrm{~m}^{3} \mathrm{~s}^{-1}\right)$; the Portinho River $\left(8.8 \mathrm{~m}^{3} \mathrm{~s}^{-1}\right)$; the Mazomba River $\left(0.5 \mathrm{~m}^{3} \mathrm{~s}^{-1}\right)$ and the Cação River $\left(1.1 \mathrm{~m}^{3} \mathrm{~s}^{-1}\right)$. The other rivers are water bodies of smaller basins, with very low flows. The Guandu River is the most important contributor of the basin and it is responsible for supplying water to several cities, being the main source of water for Rio de Janeiro city (Cunha et al., 2006).

The water that supplies the Rio de Janeiro metropolitan region and some Baixada Fluminense municipalities comes from Guandu Watershed, and its treatment is done by the State Company for Water and Sewage (CEDAE), responsible for a flow rate of approximately $40 \mathrm{~m}^{3} / \mathrm{s}$. In Rio de Janeiro, it has great importance for the population, as the only source of water supply for over 12 million people, including $80 \%$ of metropolitan area inhabitants (Castro and Ferreirinha, 2012).

\subsection{Reagents and materials}

All glassware was washed with extran $(5 \% \mathrm{v} / \mathrm{v})$, with $\mathrm{HNO}_{3}$ solution $1: 1(\mathrm{v} / \mathrm{v})$ and finally with deionised water. All solutions were prepared with "analytical grade" reagents (Merck or Sigma) and deionised water purified through the Milli-Q system (Millipore). The reference solutions to obtain the analytical curves for the determination of metals in soil samples were prepared by serial dilution of stock solutions of $1000 \mathrm{mg} \mathrm{L}^{-1}$ (Qhemis) of $\mathrm{As}, \mathrm{Cd}, \mathrm{Cr}, \mathrm{Co}, \mathrm{Pb}$, $\mathrm{Cu}, \mathrm{Ni}$ and $\mathrm{Zn}$ in $\mathrm{HNO}_{3} 1.0 \mathrm{~mol} \mathrm{~L}-1$.

\subsection{Sampling}

There are 261 industrial occupants of the study area according to data obtained from the Federation of Industries of Rio de Janeiro (FIRJAN). However, for this study only enrolled representatives of metallurgical (16), chemical (40) and rubber and plastic (19) sectors were included, encompassing a total of 75 industries, including the sources of most pollutants. The five sampling stations represent the sectors occupied by these industries in the area investigated (Figure 2). Their coordinates were recorded with the aid of a GPS device:

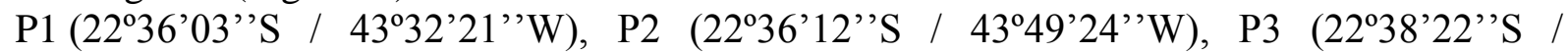

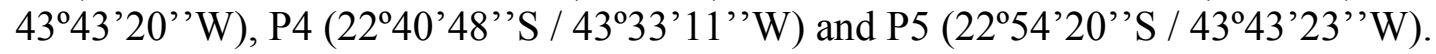

From February 2013 to December 2014, five (5) soil samples were collected at each of the sampling stations in the Guandu watershed. For control, a few samples were used in presumably uncontaminated areas outside of the direct effect of the chemical industries. Duplicate soil samples (depth $0-20 \mathrm{~cm}$ ) were collected along the sampling stations by using a polyethylene tube with a $4 \mathrm{~cm}$ diameter and were stored in plastic bags. Most of the soil samples were collected from the upper surface of the soil with depth ranging from $5-10 \mathrm{~cm}$. It has been demonstrated by Chang et al. (1984) that more than $90 \%$ of applied toxic metals in soil are found at a depth of $15 \mathrm{~cm}$ from the surface. However, there are many authors who report maximum toxic metal concentration in the surface layer from up to $6 \mathrm{~cm}$ (Haiyan and Stuanes, 2003; Iwegbue et al., 2006). Generally content of toxic metals is significantly higher in top soil than in subsoil with a very few exceptions as they have little downward movement because of their strong affinities with soil solid phase (Banuelos and Ajwa, 1999; Sterckeman 
et al., 2000). The two pristine soil samples (C1 and C2) were collected from sites 5 to $30 \mathrm{~km}$ away from the study site, which showed no evidence of human disturbance. In the laboratory, the samples were dried at $40-50^{\circ} \mathrm{C}$ and were sieved through plastic-only sieves into $<2 \mathrm{~mm}$ fraction. Before and after sieving, the samples were homogenized and quartered and then grinded in an agate mortar.

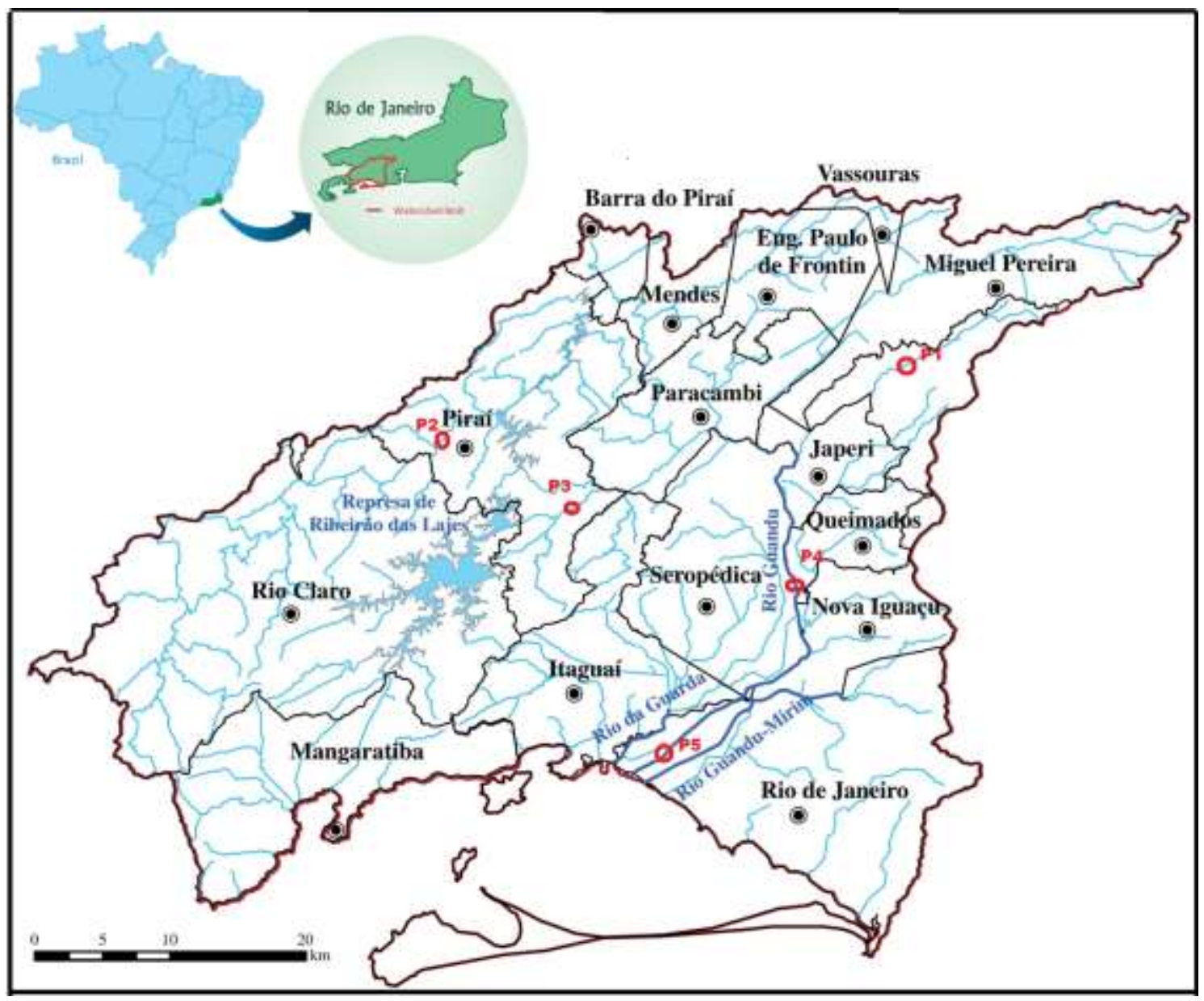

Figure 2. Study site: Guandu Watershed. P indicates sampling stations, 2013-2014.

Source: Comitê Guandu (2012).

\subsection{Soil parameters}

The values of $\mathrm{pH}$ and organic matter content in the soil samples were also determined. Fifteen grams of sample soil were dissolved in $15 \mathrm{ml}$ of deionised water, and after mixing for $24 \mathrm{~h}$ the measurement of $\mathrm{pH}$ was done with a $\mathrm{pH}$-meter. Inorganic matter content was evaluated according to the Loss on Ignition (LOI) method. Samples were dried in order to eliminate water content. Subsequently, they were heated for $2 \mathrm{~h}$ at $600^{\circ} \mathrm{C}$ and weight loss was assessed.

\subsection{Metals}

Metals assessed in this study were selected based upon the degree of toxicity (ATSDR, 2007). For each sampling location, composite samples were collected approximately from $200 \mathrm{~g}$ of soil collected with stainless steel implements from a depth of $0.2 \mathrm{~m}$. For laboratorial analyses, $0.5 \mathrm{~g}$ of dried samples of soil was treated with $5 \mathrm{ml}$ of nitric acid (65\% Suprapur, Merck, Darmstadt, Germany) in Teflon vessels for $8 \mathrm{~h}$ at room temperature. Subsequently, the samples were heated at $80^{\circ} \mathrm{C}$ in a stove for $8 \mathrm{~h}$. After cooling, solutions were filtered and 
filled up to $25 \mathrm{ml}$ with deionised water. The determination of elements (As, $\mathrm{Cd}, \mathrm{Zn}, \mathrm{Cu}, \mathrm{Pb}$, $\mathrm{Cr}, \mathrm{Ni}$, and $\mathrm{Co}$ ) was performed by the optical emission spectrometry method in inductive plasma (Inductively Coupled Plasma-Optical Emission Spectrometry, ICP) with a physical argon flame. In order to define wavelengths in the ICP, we initially tested all of the possibilities offered by the device, both in the axial view and in the radial plane. For each element, the design spectrum of a solution containing only the chemical species was determined in order to identify and adjust the emission peak of the element. A reading of the blank was made in a sample and the maximum point of the calibration curve in order to investigate possible spectral interferences and, if possible, minimize them, by making adjustments to the baselines, delimiting the peak area. After these adjustments, a reading of the calibration curve was made by selecting the wavelengths that showed the coefficient of determination of the linear model $\left(\mathrm{R}^{2}\right)$ closer to 1 and with minimal spectral interference. Accuracy and reproducibility of the methods were tested using muscle (DORM-2, National Research Council, Canada) certified material. Standards and blanks were analysed along with each set of samples. Concentrations are expressed as (mg. $\mathrm{kg}^{-1}$ dry weight).

\subsection{Statistical analysis}

Statistical analysis was undertaken using an Origin 7.5 software package (OriginLab Corporation). The average distribution of the pollutants throughout the soil was assessed using analysis of variance (ANOVA). In order to determine which metal was significantly different from the other, a post-hoc comparison was carried out using Turkey's multiple comparison tests. For all the tests, p-values of $<0.05$ were used to determine significant differences.

\section{RESULTS AND DISCUSSION}

The $\mathrm{pH}$ values obtained ranged from 4.7 to 6.9. The transport and accumulation of organic matter, nutrients and trace metals and their biogeochemical cycles are strongly affected by land uses, including agriculture, industrial and urban uses. An analysis of soil fertility, based upon soil particulate size in the area studied, revealed a high proportion of sand with small percentages of silt and clay (Table 2).

Table 2. Mean data of soil fertility analysis from Guandu Watershed and pristine control, 2013-2014.

\begin{tabular}{lccccccc}
\hline \multirow{2}{*}{ Parameters } & \multicolumn{7}{c}{ Samples zone } \\
\cline { 2 - 8 } & $\mathrm{P} 1$ & $\mathrm{P} 2$ & $\mathrm{P} 3$ & $\mathrm{P} 4$ & $\mathrm{P} 5$ & $\mathrm{C} 1$ & $\mathrm{C} 2$ \\
\hline $\mathrm{pH}$ & 5.2 & 4.7 & 6.9 & 5.0 & 6.1 & 5.3 & 5.4 \\
$\mathrm{Al}\left(\mathrm{g} \cdot \mathrm{kg}^{-1}\right)$ & 6.34 & 4.44 & 2.45 & 4.56 & 3.3 & 0.31 & 0.22 \\
$\mathrm{Ca}\left(\mathrm{g} \cdot \mathrm{kg}^{-1}\right)$ & 0.18 & 0.22 & 0.25 & 0.19 & 0.17 & 0.23 & 0.19 \\
$\mathrm{Mg}\left(\mathrm{g} \cdot \mathrm{kg}^{-1}\right)$ & 0.11 & 0.14 & 0.08 & 0.05 & 0.07 & 1.2 & 1.0 \\
$\mathrm{Na}\left(\mathrm{g}_{\mathrm{kg}} \mathrm{kg}^{-1}\right)$ & 0.02 & 0.04 & 0.02 & 0.02 & 0.03 & 0.03 & 0.04 \\
$\mathrm{~N}\left(\mathrm{~g} \cdot \mathrm{kg}^{-1}\right)$ & 6.33 & 5.67 & 3.45 & 4.41 & 2.99 & 9.38 & 9.77 \\
$\mathrm{~K}\left(\mathrm{~g} \cdot \mathrm{kg}^{-1}\right)$ & 1.22 & 1.18 & 1.43 & 1.26 & 1.461 & 2.15 & 2.67 \\
$\mathrm{P}\left(\mathrm{g} \cdot \mathrm{kg}^{-1}\right)$ & 0.09 & 0.03 & 0.06 & 0.15 & 0.18 & 0.16 & 0.21 \\
$\mathrm{Carbon}(\%)$ & 0.12 & 0.23 & 0.45 & 0.32 & 0.66 & 0.37 & 0.68 \\
\hline
\end{tabular}

The possibility of seasonal variation of pollutant levels demonstrated reinforces the need for soil monitoring in the area. Soil contamination can vary over time depending on the frequency of the release of contaminants in the environment. Industrial contaminants typically 
tend to behave this way because their addition to the medium varies with the product manufactured, problems in operating procedures, climatic and economic factors.

Both contamination and pollution involve the disturbance of the natural state of the environment by anthropogenic activity. The two terms are distinguishable by the severity of the effect: pollution induces the loss of potential resources. In the marine environment, human-induced disturbances take many forms. Due to source strengths and pathways, the greatest effects tend to be in the coastal zone. Waters and soil in such regions bear the main blow of industrial and sewage discharges and are subject to spoil dumping. Table 3 shows that the concentrations found in all samples greatly exceeded the natural levels.

Table 3. Results obtained in laboratorial soil analyses performed for metal distribution at Guandu Watershed, 2013-2014.

\begin{tabular}{lrrrrrrrr}
\hline \multirow{2}{*}{$\begin{array}{c}\text { Sampling } \\
\text { stations }\end{array}$} & \multicolumn{7}{c}{ Elements (mg.kg-1 dry weight) } \\
\cline { 2 - 9 } & \multicolumn{1}{c}{ As } & \multicolumn{1}{c}{ Cd } & \multicolumn{1}{c}{ Zn } & Cu & Pb & Cr & Ni & Co \\
\hline P1 & 35.8 & 9.7 & 376.2 & 122.6 & 234.9 & 119.6 & 14.5 & 28.5 \\
P2 & 74.9 & 13.6 & 862.7 & 251.4 & 416.3 & 245.4 & 39.3 & 53.4 \\
P3 & 66.7 & 16.6 & 643.9 & 235.8 & 329.6 & 225.8 & 34.5 & 32.8 \\
P4 & 47.1 & 6.9 & 247.8 & 233.6 & 238.3 & 122.5 & 22.4 & 17.3 \\
P5 & 126.6 & 19.2 & 738.5 & 519.7 & 641.2 & 362.3 & 111.2 & 64.6 \\
C1 & 3.5 & 0.5 & 12.8 & 14.9 & 31.2 & 11.4 & 2.3 & 4.5 \\
C2 & 11.2 & 0.8 & 4.3 & 25.7 & 18.6 & 5.3 & 4.7 & 6.9 \\
\hline
\end{tabular}

The levels of occurrence of metals in soil related to the soil's source material and therefore are considered naturally occurring both by the standard Dutch as CETESB (2005). There is a background value of Brazilian soil (CONAMA, 2009) which complicates the interpretation of data obtained from sampling campaigns for research, because many factors can influence the occurrence of metals in soil, making it difficult to quantify the levels found in anthropogenic areas.

Metal concentrations in soil are strongly determined by influences, which was the main source of contamination at the studied site. Industrial effluent is likely to be the major source of metal concentrations because of anthropogenic actions (Hämäläinen et al., 2009; Araújo, 2010). The data obtained from this research were higher than the results found by Araújo (2010) in the analysis of metals in soils of the Apodi-Mossoró/RN river basin in urban Mossoró-RN. Similarly, the levels obtained were higher than the values reported by $\mathrm{Su}$ and Yang (2008) for Asian soil in relation to $\mathrm{Cr}\left(55.8 \mathrm{mg} . \mathrm{kg}^{-1}\right), \mathrm{Zn}\left(33.7 \mathrm{mg} . \mathrm{kg}^{-1}\right)$, $\mathrm{Cu}\left(5.1 \mathrm{mg} . \mathrm{kg}^{-1}\right), \mathrm{Ni}\left(17 . \mathrm{mg} . \mathrm{kg}^{-1}\right), \mathrm{Pb}\left(15 . \mathrm{mg} . \mathrm{kg}^{-1}\right),\left(5.2 \mathrm{mg} \cdot \mathrm{kg}^{-1}\right)$ and $\mathrm{Co}\left(5.7 \mathrm{mg} . \mathrm{kg}^{-1}\right)$.

The metal levels in industrial areas (P2, P3, P5) were higher than those close to urban areas (P1, P4) and identified the critical points of contamination. The results indicate the potential paths of metals through the soil transport of industrial areas for the Guandu Watershed.

Most legislation regarding environmental conservation, management and the sustainable use of coastal natural resources fails to consider human activities in catchment basins, These activities are sometimes far from the coast. Also, many socio-economic driving forces acting on river catchments may be completely different from those acting on coastal areas. A general problem is a scaling mismatch between legal instruments and 
coastal issues as well as with drivers of change and legislation, rather than low-quality environmental laws. As a result, despite a strengthening of environmental regulations for many coastal areas around the world, potential beneficial effects of these regulations on the quality of coastal environments are being overtaken by detrimental impacts generated in catchment basins.

\section{CONCLUSION}

The results demonstrated that metal concentrations are below the maximum limits established for soil by CONAMA. Indeed, given the magnitude of industrialization in the area evaluated, the current results suggest that chemical facilities located in the industrial complexes of Rio de Janeiro are a relevant source of pollution by metals. Moreover, the presence of these industries poses a notable risk for the health of the population living in the vicinity. A monitoring program is therefore clearly desirable, while some efforts should be focused on decreasing environmental levels of polluting elements.

\section{ACKNOWLEDGEMENT}

I would like to thank Atomic Absorption Laboratory, Pontifical Catholic University of Rio de Janeiro, for metal identification.

\section{REFERENCES}

AGENCY FOR TOXIC SUBSTANCES AND DISEASE REGISTRY (United States). CERCLA priority list of hazardous substances. Atlanta: ATSDR, 2007.

ARAÚJO, J. B. S. Identificação de fontes poluidoras de metais pesados nos solos da bacia hidrográfica do rio Apodi-Mossoró/RN, na área urbana de Mossoró-RN. Revista Verde, v. 5, n. 2, p. $80-94,2010$.

BANUELOS, G. S.; AJWA, H. A. Trace elements in soil and plants: an overview. Journal of Environmental Science and Health, Part A, v. 4, p. 951-974, 1999. http://dx.doi.org/10.1080/10934529909376875

BERTOLOTTO, R. M.; TORTAROLO, B.; FRIGNANI, M.; BELlUCCI, L. G.; ALBANESE, S.; CUNEO, C. Heavy metals in surficial coastal sediments of the Ligurian Sea. Marine Pollution Bulletin, v. 50, n. 3, p. 348-356, 2005. http://dx.doi.org/10.1016/j.marpolbul.2004.12.002

BINNING, K.; BAIRD, D. Survey of heavy metals in the sediments of the Swartkops River Estuary, Port Elizabeth South Africa. Water South Africa, v. 27, n. 4, p. 461-465, 2001. http://dx.doi.org/10.4314/wsa.v27i4.4958

CAHEN, B. Implementation of new legislative measures on industrial risks prevention and control in urban areas. Journal of Hazardous Materials, v. 130, n. 3, p. 293-299, 2006. http://dx.doi.org/10.1016/j.jhazmat.2005.07.029

CASADO-MARTÍNEZ, M. C.; BUCETA, J. L.; BELZUNCE, M. J.; DEL VALLS, T. A. Using sediment quality guidelines for dredged material management in commercial ports from Spain. Environment International, v. 32, p. 388-396, 2006. http://dx.doi.org/10.1016/j.envint.2005.09.003 
CASTRO, C. M.; FERREIRINHA, M. M. A problemática ambiental na bacia hidrográfica do rio Guandu: desafios para a gestão dos recursos hídricos. Anuário do Instituto de Geociências, v. 35, n. 2, p. 71-77, 2012. http://dx.doi.org/10.11137/2012_2_71_77

COMITÊ DA BACIA HIDROGRÁFICA GUANDU (Rio de Janeiro). Bacia hidrográfica dos Rios Guandu, da Guarda e Guandu-Mirim: experiências para a gestão dos recursos hídricos. Rio de Janeiro, 2012. Disponível em:

http://www.comiteguandu.org.br/conteudo/livroguandu2013.pdf. Acesso em: ago. 2015.

COMPANHIA AMBIENTAL DO ESTADO DE SÃO PAULO - CETESB. Decisão de Diretoria $\mathbf{N}^{\mathbf{0}}$. 195-2005-E, de 23 de novembro de 2005. Dispõe sobre a aprovação dos Valores Orientadores para Solos e Águas Subterrâneas no Estado de São Paulo, em substituição aos Valores Orientadores de 2001. São Paulo, 2005.

CONSELHO NACIONAL DO MEIO AMBIENTE - COMANA (Brasil). Resolução no 420/2009. Dispõe sobre critérios e valores orientadores de qualidade do solo quanto à presença de substâncias químicas e estabelece diretrizes para o gerenciamento ambiental de áreas contaminadas por essas substâncias em decorrência de atividades antrópicas. Diário Oficial [da] União, n. 249, de 30 dez. 2009, p. 81-84.

COSTA, L. C.; FERREIRA, A. P.; NEVES, E. B. Aplicação do sistema de projeção de poluição industrial (Modelo IPPS) na bacia hidrográfica da baía de Sepetiba (Rio de Janeiro, Brasil): estudo de caso. Cadernos Saúde Coletiva, v. 19, p. 66-73, 2011.

CUNHA, C. L. N.; ROSMAN, P. C. C.; FERREIRA, A. P.; MONTEIRO, T. C. N. Hydrodynamics and water quality models applied to Sepetiba Bay. Continental Shelf Research, v. 26, p. 1940-1953, 2006. http://dx.doi.org/10.1016/j.csr.2006.06.010

CHANG, A. C.; WARNEKE, J. E; PAGE, A. L.; LUND, L. J. Accumulation of heavy metals in sewage sludge treated soil. Journal of Environmental Quality, v. 13, p. 87-91, 1984. http://dx.doi.org/10.2134/jeq1984.00472425001300010016x

FERREIRA, A. P. Public health and environmental pollution: precautionary paradigms. Revista Brasileira em Promoção da Saúde, v. 21, p. 69-74, 2008.

FERREIRA, A. P.; HORTA, M. A. P. Trace element residues in water, sediments, and organs of Savacu (Nycticorax nycticorax) from Sepetiba Bay, Rio de Janeiro, Brazil. Revista Ambiente \& Água, v. 5, n. 1, p. 17-28, 2010. http://dx.doi.org/10.4136/ambi-agua.116

FERREIRA, A. P. Assessment of heavy metals in Egretta thula. Case study: Coroa Grande mangrove, Sepetiba Bay, Rio de Janeiro, Brazil. Brazilian Journal of Biology, v. 71, n. 1, p. 77-82, 2011. http://dx.doi.org/10.1590/S1519-69842011000100012

FEDERAÇÃO DAS INDÚSTRIAS DO ESTADO DO RIO DE JANEIRO - FIRJAN. Índice FIRJAN de desenvolvimento municipal - IFDM. Rio de Janeiro, 2005.

FREITAS, M. B.; BRILHANTE, O. M.; ALMEIDA, L. M. Importância da análise de água para a saúde pública em duas regiões do Estado do Rio de Janeiro: enfoque para coliformes fecais, nitrato e alumínio. Cadernos de Saúde Pública, v. 17, n. 3, p. 651660, 2001. http://dx.doi.org/10.1590/S0102-311X2001000300019

FRIGNANI, M.; BELLUCCI, L.G. Heavy metals in marine coastal sediments: Assessing sources, fluxes, history and trends. Annali di Chimica, v. 94, p. 1-8, 2004. http://dx.doi.org/10.1002/adic.200490061 
GRAY, W. B.; SHADBEGIAN, R. J. Optimal pollution abatement-whose benefits matter, and how much? Journal of Environmental Economics and Management, v. 47, n. 3, p. 510-534, 2004. http://dx.doi.org/10.1016/j.jeem.2003.01.001

HAIYAN, W.; STUANES, A. O. Heavy metal pollution in air-water-soil-plant system of Zhuzhou city, Hunan province, China. Water, Air \& Soil Pollution, v. 147, p. 79-107, 2003. http://dx.doi.org/10.1023/A:1024522111341

HÄMÄLÄINEN, P.; SAARELA, K. L.; TAKALA, J. Global trend according to estimated number of occupational accidents and fatal work-related diseases at region and country level. Journal of Safety Research, v. 40, p. 125-139, 2009.

http://dx.doi.org/10.1016/j.jsr.2008.12.010

IWEGBUE, C. M. A.; ISIRIMAH, N. O.; IGWE, C.; WILLIAMS, E. S. Characteristic levels of heavy metals in soil profiles of automobile mechanic waste dumps in Nigeria. Environmentalist, v. 26, p. 123-128, 2006. http://dx.doi.org/10.1007/s10669-006$7482-0$

LANDROT, G.; TAPPERO, R.; WEBB, S. M.; SPARKS, D. L. Arsenic and chromium speciation in an urban contaminated soil. Chemosphere, v. 88, n. 10, p. 1196-1201, 2012. http://dx.doi.org/10.1016/j.chemosphere.2012.03.069

LEAL NETO, A. C.; LEGEY, L. F.; GONZÁlEZ-ARAYA, M. C.; JABLONSKI, S. A system dynamics model for the environmental management of the Sepetiba Bay Watershed, Brazil. Environmental Management, v. 38, n. 5, p. 879-888, 2006. http://dx.doi.org/10.1007/s00267-005-0211-5

LI, J.; LI, F.; LIU, Q.; ZHANG, Y. Trace metal in surface water and groundwater and its transfer in a Yellow River alluvial fan: Evidence from isotopes and hydrochemistry. Science of the Total Environment, v. 472C, p. 979-988, $2013 \mathrm{a}$. http://dx.doi.org/10.1016/j.scitotenv.2013.11.120

LI, H.; QIAN, X.; WANG, Q. Heavy metals in atmospheric particulate matter: a comprehensive understanding is needed for monitoring and risk mitigation. Environmental Science \& Technology, v. 47, n. 23, p. 13210-13211, 2013 b. http://dx.doi.org/10.1021/es404751a

MEYBECK, M.; DÜRR, H. H.; VÖRÖSMARTY, C. J. Global coastal segmentation and its river catchment contributors: A new look at land-ocean linkage. Global Biogeochemical Cycles, v. 20, GB1S90, 2006. http://dx.doi.org/10.1029/2005GB002540.

MIRANDA FILHO, A.; DA MOTA, A.; CRUZ, C.; MATIAS, C.; FERREIRA, A.P. Cromo hexavalente em peixes oriundos da Baía de Sepetiba no Rio de Janeiro, Brasil: uma avaliação de risco à saúde humana. Revista Ambiente \& Água, v. 6, n. 3, p. 200-209, 2011. http://dx.doi.org/10.4136/ambi-agua.568

SHANBEHZADEH, S.; DASTJERDI, M. V.; HASSANZADEH, A.; KIYANIZADEH, T. Heavy metals in water and sediment: a case study of Tembi River. Journal of Environmental and Public Health, v. 2014, article ID 858720, 5 p., 2014. http://dx.doi.org/10.1155/2014/858720 
SHERMAN, L. S.; BLUM, J. D.; DVONCH, J. T.; GRATZ, L. E.; LANDIS, M. S. The use of $\mathrm{Pb}, \mathrm{Sr}$, and $\mathrm{Hg}$ isotopes in Great Lakes precipitation as a tool for pollution source attribution. Science of the Total Environment, v. 502, p. 362-374, 2015. http://dx.doi.org/10.1016/j.scitotenv.2014.09.034

SLATIN, C. Environmental and occupational health and human rights. New Solutions: A Journal of Environmental and Occupational Health Policy, v. 21, n. 2, p. 177-195, 2011. http://dx.doi.org/10.2190/NS.21.2.c

STERCKEMAN, T.; DOUAY, F.; PRIOX, N.; FOURRIER, H. Vertical distribution of Cd, $\mathrm{Pb}$ and $\mathrm{Zn}$ in soil near smelters in the North of France. Environmental Pollution, v. 107, p. 377-389, 2000. http://dx.doi.org/10.1016/S0269-7491(99)00165-7

SU, Y.; YANG, R. Background concentrations of elements in surface soils and their changes as affected by agriculture use in the desert-oasis ecotone in the middle of Heihe River Basin, North-west China. Journal of Geochemical Exploration, v. 98, p. 57-64, 2008. http://dx.doi.org/10.1016/j.gexplo.2007.12.001

TEMMERMAN, S.; MEIRE, P.; BOUMA, T. J.; HERMAN, P. M.; YSEBAERT, T.; DE VRIEND, H. J. Ecosystem-based coastal defence in the face of global change. Nature, v. 504, n. 7478, p. 79-83, 2013. http://dx.doi.org/10.1038/nature12859

UNITED STATES. Environmental Protection Agency - US-EPA. Integrated Risk Information System (IRIS). Washington DC: National Center for Environmental Assessment, Office of Research and Development, 1999.

WANG, X. C.; FENG, H.; MA, H. Q. Assessment of metal contamination in surface sediments of Jiaozhou Bay, Qingdao, China. Clean, v. 35, n. 1, p. 62-70, 2007. http://dx.doi.org/10.1002/clen.200600022

WANG, Y.; LIU, D.; RICHARD, P.; LI, X. A geochemical record of environmental changes in sediments from Sishili Bay, northern Yellow Sea, China: Anthropogenic influence on organic matter sources and composition over the last 100 years. Marine Pollution Bulletin, v. 77, n. 1-2, p. 227-236, 2013.

http://dx.doi.org/10.1016/j.marpolbul.2013.10.001 